\title{
Diuretics and Carbohydrate Metabolism: The Effects of Furosemide and Amiloride on Blood Glucose, Plasma Insulin and Cations in the Rat*
}

\author{
A. Aynsley-Green** and K.G. Alberti \\ Nuffield Department of Clinical Medicine, The Radeliffe Infirmary, Oxford, England
}

Received: September 18, 1972, accepted: October 20, 1972

\begin{abstract}
Summary. The effects of two unrelated diuretics, furosemide and amiloride on blood glucose, plasma insulin and glucose tolerance in the conscious rat are reportod. Furosemide $(1 \mathrm{mg} / \mathrm{kg}$ or $2 \mathrm{mg} / \mathrm{kg})$ given intravenously caused an immediate but highly transient $23 \%$ and $53 \%$ fall in plasma insulin followed by a rise in blood glucose. The hyperglycaemic effect alone occurred in mild streptozotocin diabetic animals. Furosemide given with or $30 \mathrm{~min}$ before intravenous glucose $(0.5 \mathrm{G} / \mathrm{kg})$ caused glucose intolerence with diminished insulin response. None of these effects were observed in adrenalectomised animals. Amiloride $(1,5$ or $10 \mathrm{mg} / \mathrm{kg})$ given I.V. alone immediately increased plasma insulin (up to $213 \mu \mathrm{U} / \mathrm{ml}$ ) without affecting blood glucose. This effect was attenuated by
\end{abstract}

mild streptozotocin diabetes. Amiloride given with or 30 min before glucose increased the insulin area without affecting glucose disappearance. Chronic administration enhanced glucose disappearance with increased plasma insulin responsc, and caused hyperkalaemia. Chronic furosemide administration had no effects. Possible mechanisms for these effects are discussed.

Key words: Diuretics; glucose intolerance; furosemide; amiloride; plasma immunoreactive insulin; blood glucose; intravenous glucose tolerance; streptozotocin - diabetic rats; adrenalectomised rats; plasma sodium and potas. sium; red cell sodium and potassium; total body sodium and potassium.

\section{Introduction}

Glucose intolerance following diuretic therapy has been reported in man and in experimental animals, although the mechanism of the effect, its incidence and clinical importance remain controversial. Benzothiadiazine diuretics are known to exacerbate hyperglycaemia in diabetic patients (for review, see [1]) and frequently to cause impaired carbohydrate tolerance in hypertensive patients [1]. Prospective studies in normal subjects [2] and non-diabetic hypertensive patients $[3,4]$ have shown that most patients who cievelop glucose intolerance have a diabetic predisposition, although prednisone-primed glucose tolerance tests or tolbutamide tests may reveal abnormalities in others $[\mathbf{5}, \mathbf{6}]$. Animal studies have given conflicting results, showing hyperglycaemia $[7,8,9]$, impaired glucose tolerance $[10]$ or no effect $[11,12]$. Acute diuretic induced hyperglycaemia using large doses of diuretics under ether anaesthesia has been described in the rodent $[13,14,15]$, but few studies have examined sequential insulin changes in conscious animals. Further studies using small doses therefore seemed necessary, first to establish whether there was a consistent effect and second to examine the mechanisms involved.

Two hiuretics were used, furosemide (Lasix) related to the benzothiadiazines, and amiloride (Midamor) a non-thiazide diuretic. Furosemide contains the thiazide

* Presented in part at the $7 \mathrm{th}$ Annual meeting of the European Association for the study of diabetes, Southampton. 1971

** Wellcome Junior Research Fellow. sulphamoyl anthranilic acid structure, but the thiadiazine ring is replaced by a furfuryl group (Fig. 1). It has been suggested that kaliuretic diuretics such as this may cause glucose intolerance secondary to potassium depletion, since potassium depletion is associated with diminished glucose tolerance [16]<smiles>Nc1nc(N)c(C(=O)NC(N)N)nc1Cl</smiles><smiles>COC(=O)Oc1cc(Cl)c(ON)cc1NCc1ccco1</smiles>

Fig. 1. The structuros of amiloride and furosemide

whilst repletion improves tolerance [17]. Amiloride is a pyrazine-carbonylguanidine which is structurally unrelated to the thiazides, has a weaker natriuretic effect and does not cause potassium loss [18]. The guanidine group of amiloride is shared by arginine, a potent stimulus to insulin secretion (Fig. 1). It might therefore be predicted that furosemide and amiloride would have opposite effects on insulin secretion and glucose metabolism. 

below.

Results confirming this hypothesis are presented

\section{Materials and Methods}

Special Chemicals: Pure furosemide was a gift from Hoochst Pharmaceuticals, Ltd., and used at a final concentration of 1 and $2 \mathrm{mg} / \mathrm{ml}$ in normal saline, $\mathrm{pH} 7.0$ 7.4. Pure amiloride hydrochloride, a gift from Merck, Sharp and Dohme Ltd., was injected as a suspension in normal saline at concentrations of 1,5 and $10 \mathrm{mg} / \mathrm{ml}$. Anti-insulin serum was a gift from Dr. P.H. Wright; $\mathrm{I}^{126}$.insulin was purchased from Abbott Laboratories, Chicago, U.S.A. Streptozotocin was kindly provided by the Upjohn Co., Kalamazoo, Michigan, U.S.A. Ultra pure water was obtained by passing distillod water through an Elgacan ion exchange column (Elga Products Ltd., Lane End, Bucks).

Analytical methods: Insulin was assayed by a micromodification of the double antibody radioimmunosssay of Soeldner and Slone [19] with ethylene diamine tetracetic acid (EDTA) present throughout the assay [20]. Purified rat insulin (kindly supplied by Novo Industri $\mathrm{A} / \mathrm{S}$ Copenhagen) was used as the insulin standard. The assay was unaffectod by furosemide and amiloride and allowed the measurement of $1 \mu \mathrm{U}$ insulin/ml in $50 \mu \mathrm{l}$ plasma samples, derived from EDTA treated blood. Glucose was measured in a neutralised perchloric acid extract of whole blood by a glucose oxidase method [21].

Sodium and potassium were measured by flame photometry using an E.E.L. integrating flame photometer with a lithium internal standard. Ammonium heparin plasma and red cell haemolysates were assayod after diluting 1: 100 with lithium working diluent. No correction was made for plasma trapping. Whole body sodium and potassium values were obtained by assaying the nitric acid digest of the minced carcas.

Animals: Malo white Wistar rats weighing 250 to $350 \mathrm{gm}$ were used unless otherwise stated. Adrenalectomised Wistar rats (Scientific Products Farm, Ash, Canter. bury), maintained on $0.9 \%$ saline, were used $5-10$ days aftor adrenalectomy. Diabetic rats were obtained by intraperitoneal injection of $60 \mathrm{mg} / \mathrm{kg}$ or $75 \mathrm{mg} / \mathrm{kg}$ streptozotocin $48 \mathrm{~h}$ beforo the experiments.

Experimental model: Conscious overnight-starved rats were used $16-20 \mathrm{~h}$ after the insertion of small cannulae $(0.4 \mathrm{~mm}$ internal diamoter) into the left femoral artery and vein under light ether anaesthesia. The animals were kept in restraining cages with free access to water. Cannulae wero kept patent with saline. Up to $0.35 \mathrm{ml}$ arterial blood was withdrawn at each sample time, the volume boing replaced with saline. Up to ten samples could be withdrawn without changes in glucose or insulin.

Immediately on withdrawing, $100 \mu \mathrm{l}$ of blood were added to $2 \mathrm{ml} 2 \%$ perchloric acid for subsoquent glucose assay and the remaining $0.2-0.25 \mathrm{ml}$ wero added to EDTA for insulin assay. Additional $0.4 \mathrm{ml}$ blood samples wore taken where epplicable for plasma and red cell sodium and potassium assay.

Acute experiments: The diuretics were given as acute IV boluses either alone, with, or thirty minutes before a standard glucose dose of $0.5 \mathrm{~g} / \mathrm{kg}$ body weight. The latter was given intravenously as a $50 \%$ solution (w/v) in $15 \mathrm{sec}$ and subsequent timing of samples was made from the end of the glucose infusion.

Chronic experiments: Groups of animals were given daily intraperitoneal injections of either furosemide $2 \mathrm{mg} /$ $\mathrm{kg}$ or $10 \mathrm{mg} / \mathrm{kg}$ ainiloride. Control animals of similar woight were givon an equivalent volume of intraperitoneal saline. After 30 days (furosemide) and 10 days (amiloride) intravenous glucose tolerance tests were performod, $24 \mathrm{~h}$ after the last doso of diuretic.
Calculations: The glucose disappearance rate $(\mathrm{kg})$ was calculated using the absolute blood glucose values from 2.5-20 min [22]. Insulin areas were calculated from the areas under the insulin curves during the first five, ten, or thirty minutes of the test. $\frac{\Delta \mathrm{I}}{\Delta \bar{G}}$ ratios were calculated from the increments of plasma insulin and blood glucose values from the zero value [23]. Statistical significance was assessed by the Student ' $t$ ' test.

\section{Results}

\section{The effects of acute administration of furosemide on blood glucose and plasma insulin}

a) Normal animals: A significant decrease in plasma insulin occurred with both $1 \mathrm{mg}$ and $2 \mathrm{mg} / \mathrm{kg}$ furosemide (Fig. 2; Table 1). Plasma insulin fell by $23 \%$
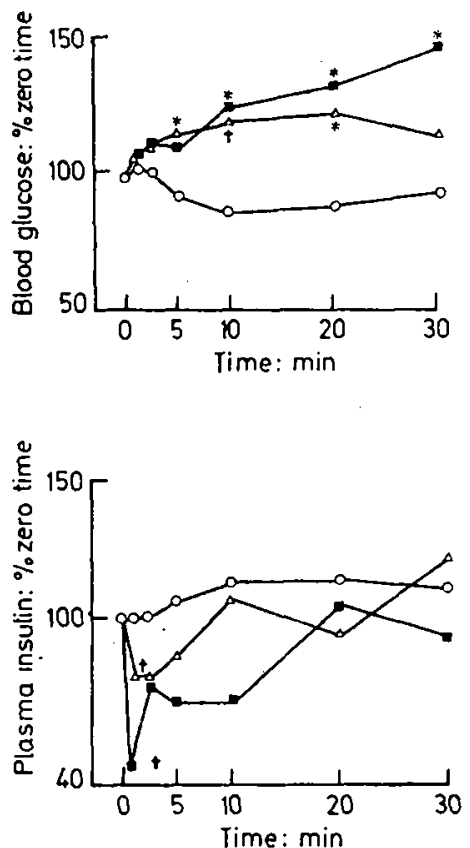

Fig. 2. The effects of acute administration of furosemide on blood glucose and plasma insulin in normal animals Furosemide, $1 \mathrm{mg} / \mathrm{kg}$, shown by $\triangle-\triangle(n=5)$, or $2 \mathrm{mg} / \mathrm{kg}$ shown by $-(n=4)$ was given as an acute intravenous injection after the time 0 sample had been drawn. Control enimals, shown by $o-0(n=6)$ received an equivalent volume of saline. Each point represents the mean of the values obtained for each group. For clarity the standard error of the mean is omitted, but significant differences, compared with control values, are shown by * $(p<0.05)$ or $f(p<0.01)$. Abscissa : time after injection. Ordinate: blood glucose and plasma insulin expresced as percentage of zero (pre-injection) value

at $1 \mathrm{~min}$ and $26 \%$ at $2.5 \mathrm{~min}$ with the lower dose $(p<0.025)$, whereas with $2 \mathrm{mg} / \mathrm{kg}$, there was a $53 \%$ decrease at one minute, the suppression persisting until $10 \mathrm{~min}$ after injection, when the plasma insulin was still $30 \%(p<0.05)$ below the fasting value. A small but significant rise in blood glucose occurred at twenty minutes with both groups and persisted to $30 \mathrm{~min}$ with 
the higher dose. Absolute blood glucose and plasma insulin values showed some variation between groups. However, changes within groups were consistent.

No significant changes in plasma insulin or blood glucose occurred in animals injected with saline alone.

b) Diabetic animals: No significant change occurred in insulin secretion in the "mild" diabetic group after furosemide $2 \mathrm{mg} / \mathrm{kg}$ and although fasting values were within the normal range a significant rise in blood glucose of $27 \%$ occurred after 20 min (Table 1). No change in blood glucose or plasma insulin occurred in the ketotic hyperglycaemic animals (Table 1). animals, animals given furosemide $1 \mathrm{mg} / \mathrm{kg}$ and $2 \mathrm{mg} /$ $\mathrm{kg}$ simultaneously with glucose, and animals pretreated with furosemide $1 \mathrm{mg} / \mathrm{kg} 30 \mathrm{~min}$ before glucose is shown in Fig. 3.

Control animals showed a glucose disappearance rate of $3.7 \pm 0.27 \% / \mathrm{min}$ (Table 2 ). Glucose disappearance was markedly decreased in the animals given furosemide either with or before glucose (Table 2), although the $2.5 \mathrm{~min}$ blood glucose value in the low dose group and the $5 \mathrm{~min}$ value in all the furosemide groups were significantly lower than in control animals (Fig. 3). However, the initial insulin response was

Table 1. Blood glucose and plasma insulin after acute administration of furosemide (土S.E.M.)

\begin{tabular}{|c|c|c|c|c|c|c|}
\hline \multicolumn{5}{|c|}{ Furosemide $2 \mathrm{mg} / \mathrm{kg}$} & \multicolumn{2}{|c|}{ Furosemide $1 \mathrm{mg} / \mathrm{kg}$} \\
\hline \multirow{2}{*}{$\begin{array}{l}\text { Time } \\
(\min )\end{array}$} & \multirow{2}{*}{$\begin{array}{l}\text { Saline } \\
\text { control }\end{array}$} & \multirow[t]{2}{*}{ Normal } & \multicolumn{2}{|l|}{ Diabetic } & \multirow{2}{*}{\multicolumn{2}{|c|}{$\begin{array}{l}\text { Adrenalec-Normal } \\
\text { tomised }\end{array}$}} \\
\hline & & & mild & moderate & & \\
\hline \multicolumn{7}{|c|}{$\begin{array}{l}\text { a) Blood glucose } \\
\mathrm{mg} / 100 \mathrm{ml}\end{array}$} \\
\hline-10 & $78 \pm 8$ & $103 \pm 8$ & $80 \pm 17$ & $262 \pm 47$ & $39 \pm 2$ & $103 \pm 6$ \\
\hline 0 & $82 \pm 2$ & $99 \pm 10$ & $82 \pm 8$ & $321 \pm 33$ & $38 \pm 3$ & $97 \pm 5$ \\
\hline 1 & $93 \pm 6$ & $97 \pm 4$ & $81 \pm 7$ & $320 \pm 28$ & $36 \pm 4$ & $102 \pm 4$ \\
\hline 2.5 & $91 \pm 9$ & $99 \pm 5$ & $83 \div 13$ & $316 \pm 27$ & $40 \pm 4$ & $107 \pm 3$ \\
\hline 5 & $78 \pm 7$ & $98 \pm 6$ & $94 \pm 22$ & $281 \pm 25$ & $38 \pm 3$ & $110 \pm 4$ \\
\hline 10 & $73 \pm 7$ & $112 \pm 2$ & $100 \pm 24$ & $306 \pm 24$ & $36 \pm 4$ & $117 \pm 3^{c}$ \\
\hline 20 & $75 \pm 11$ & $120 \pm 3^{b}$ & $109 \pm 5^{3}$ & $335 \pm 28$ & $40 \pm 4$ & $120 \pm 6^{c}$ \\
\hline 30 & $\begin{array}{l}80 \pm 12 \\
5\end{array}$ & ${ }_{4}^{123 \pm 5^{b}}$ & $\begin{array}{l}103 \pm 11 \\
3\end{array}$ & $\begin{array}{l}326 \pm 22 \\
4\end{array}$ & $\begin{array}{l}38 \pm 5 \\
11\end{array}$ & $109 \pm 9$ \\
\hline \multicolumn{7}{|c|}{$\begin{array}{l}\text { b) Plasma insulin } \\
\mu \mathrm{U} / \mathrm{ml}\end{array}$} \\
\hline-10 & $16 \pm 3$ & $19 \pm 5$ & $14 \pm 4$ & $6.0 \pm 0.8$ & $3.0 \pm 0.5$ & $34 \pm 8$ \\
\hline 0 & $17 \pm 4$ & $17 \pm 3$ & $13 \pm 4$ & $5.4 \pm 0.8$ & $2.8 \pm 0.5$ & $31 \pm 6$ \\
\hline 1 & $15 \pm 3$ & $8 \pm 2^{c}$ & $12 \pm 3$ & $5.9 \pm 0.9$ & $3.2 \pm 0.4$ & $24 \pm 4^{b}$ \\
\hline 2.5 & $15 \pm 2$ & $13 \pm 4$ & $11 \pm 3$ & $6.5 \pm 1.5$ & $3.3 \pm 0.4$ & $23 \pm 4^{\mathrm{c}}$ \\
\hline 5 & $18 \pm 2$ & $12 \pm 2^{\mathrm{c}}$ & $12 \pm 3$ & $5.5 \pm 1.3$ & $2.6 \pm 0.3$ & $22 \pm 6$ \\
\hline 10 & $17 \pm 3$ & $12 \pm 3^{b}$ & $12 \pm 4$ & $3.6 \pm 0.5$ & $2.6 \pm 0.5$ & $31 \pm 6$ \\
\hline 20 & $16 \pm 2$ & $18 \pm 4$ & $16 \pm 4$ & $5.2 \pm 0.7$ & 3.0 土 0.4 & $29 \pm 6$ \\
\hline 30 & $16 \pm 2$ & $16 \pm 5$ & $14 \pm 2$ & $4.5 \pm 0.8$ & $3.0 \pm 0.4$ & $34 \pm 4$ \\
\hline & $=$ & 4 & 3 & 4 & 6 & \\
\hline
\end{tabular}

a $p<0.05$ compared with control values;

$\left.\begin{array}{l}p<0.05 \\ \text { c } p<0.01\end{array}\right\}$ for paired differences with zero value

Mild diabetic animals received $60 \mathrm{mg} / \mathrm{kg}$ streptozotocin; moderate diabotic animals received $75 \mathrm{mg} / \mathrm{kg}$ streptozotocin.

c) Adrenalectomised animals: Mean fasting blood glucose and plasma insulin were significantly lower than in control animals (Table 1). Furosemide $2 \mathrm{mg} / \mathrm{kg}$ did not affect either parameter, implying that the decrease in plasma insulin and hyperglycaemia may have been mediated in normal animals by an adrenergic or glucocorticoid effect. Small changes in insulin would not have been detected by the methods used. However, a 30 to $\mathbf{5 0} \%$ change would have been dis. cerned.

\section{The effects of acute administration of furosemide on intravenous glucose tolerance}

a) Normal animals: The response of blood glucose and plasma insulin to $I . V$. glucose $(0.5 \mathrm{~g} / \mathrm{kg})$ in control much lower in the furosemide-treated animals (Table 2). This was not significant in the pretreated group. $\frac{\Delta \mathrm{I}}{\Delta \bar{G}}$ values were also lower, particularly in the $2 \mathrm{mg} / \mathrm{kg}$ group confirming that the plasma insulin at the early times was inappropriately low for the plasma glucose (Table 2). The thirty minute insulin area was decreased in all furosemide treated groups.

b) Adrenalectomised animals: There was no significant difference in any parameter between control adrenalectomised animals given glucose alone, and animals given glucose together with furosemide $2 \mathrm{mg} /$ $\mathrm{kg}$ ( $n=\mathbf{3}$ for each group). Mean $\mathrm{kg}$ for control animals was $2.30 \% / \mathrm{min}$ and for the furosemide group $2.33 \%$ / $\min$. 
Table 2. The effects of acute administration of furosemide and amiloride on intravenous glucose tolerance (all valucs \pm S.W.M.)

\begin{tabular}{|c|c|c|c|c|c|c|c|}
\hline \multirow{2}{*}{\multicolumn{2}{|c|}{ Saline control }} & \multicolumn{3}{|l|}{ Furosemide } & \multicolumn{3}{|l|}{ Amiloride } \\
\hline & & $1 \mathrm{mg} / \mathrm{kg}$ & $2 \mathrm{mg} / \mathrm{kg}$ & $\begin{array}{l}1 \mathrm{mg} 30 \mathrm{~min} \\
\text { before glucose }\end{array}$ & $5 \mathrm{mg} / \mathrm{kg}$ & $10 \mathrm{mg} / \mathrm{kg}$ & $\begin{array}{l}5 \mathrm{mg} / \mathrm{kg} \\
30 \mathrm{~min} \\
\text { before glu. } \\
\text { cose }\end{array}$ \\
\hline \multicolumn{8}{|c|}{ a) Glucose disappearance rate (kg) $(\% / \mathrm{min})$} \\
\hline b) Ten m & $\begin{array}{c}\text { nute insulin } \\
827 \pm 89\end{array}$ & \multicolumn{4}{|c|}{ b) Ten minute insulin area $(\mu \mathrm{U} / \mathrm{ml} / 10 \mathrm{~min})$} & $1753 \pm 405$ & $1896 \pm 560$ \\
\hline \multicolumn{8}{|c|}{ c) Thirty minute insulin area $(\mu \mathrm{U} / \mathrm{ml} / 30 \mathrm{~min})$} \\
\hline \multicolumn{8}{|l|}{ d) $\frac{\Delta I}{\Delta T}$} \\
\hline $\begin{array}{c}1 \mathrm{~min} \\
2.5 \mathrm{~min} \\
5 \mathrm{~min} \\
10 \mathrm{~min} \\
n=\end{array}$ & $\begin{array}{l}1.43 \pm 0.22 \\
1.08 \pm 0.09 \\
0.86 \pm 0.26 \\
0.74 \pm 0.17 \\
5\end{array}$ & $\begin{array}{l}0.78 \pm 0.24 \\
0.94 \pm 0.16 \\
0.42 \pm 0.14 \\
0.63 \pm 0.16 \\
5\end{array}$ & $\begin{array}{l}0.77 \pm 0.13^{\mathrm{a}} \\
0.63 \pm 0.17^{\mathrm{a}} \\
0.74 \pm 0.27 \\
0.43 \pm 0.11 \\
5\end{array}$ & $\begin{array}{l}0.70 \pm 0.06^{b} \\
0.83 \pm 0.10 \\
0.38 \pm 0.09 \\
0.40 \pm 0.09 \\
\overline{5}\end{array}$ & $\begin{array}{l}2.14 \pm 0.69 \\
3.36 \pm 1.63 \\
2.17 \pm 0.80 \\
2.04 \pm 1.20 \\
4\end{array}$ & $\begin{array}{l}1.80 \pm 0.51 \\
1.92 \pm 0.57 \\
2.52 \pm 1.00 \\
1.71 \pm 0.66 \\
5\end{array}$ & $\begin{array}{l}1.62 \pm 0.28 \\
2.08 \pm 0.55 \\
2.12 \pm 0.97 \\
0.96 \pm 0.50 \\
4\end{array}$ \\
\hline
\end{tabular}

$\left.\begin{array}{l}p<0.05 \\ \mathrm{~b} p<0.01\end{array}\right\}$ compared with control values
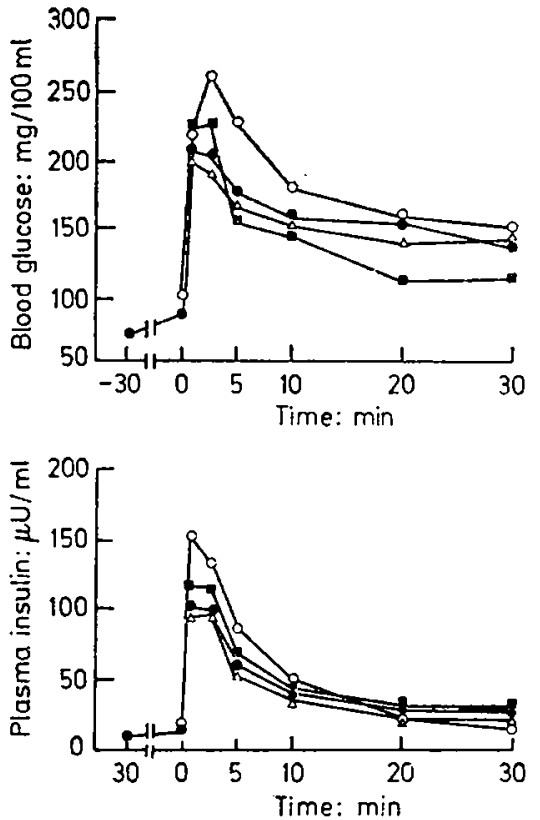

Fig. 3. The effects of acute administration of furosemide on blood glucose and plasma insulin during the intraven. ous glucose tolerance test. Furosemide $1 \mathrm{mg} / \mathrm{kg}$, shown by $\triangle-\triangle(n=5)$ or $2 \mathrm{mg} / \mathrm{kg}$ shown by $\triangle(n=5)$ was given by intravenous injection simultaneously with glucose $(0.5 \mathrm{~g} / \mathrm{kg})$ after time zero sample had been drawn. Control animals $(0-0)(n=5)$ received glucose alone. Furosemide $1 \mathrm{mg} / \mathrm{kg}$, shown by $-(n=5)$ was given $30 \mathrm{~min}$ before glucose. Each point represents the mean of the values obtained for each group

c) Chronic administration of furosemide: Intravenous glucose tolerance tests were performed after the daily intraperitoneal injection of furosemide $2 \mathrm{mg} / \mathrm{kg}$ for 30 days, and on a control group which had received an equivalent daily injection of saline. No significant differences were found.

\section{Cation changes after furosemide administration}

a) During the glucose tolerance test: When furosemide was given $30 \mathrm{~min}$ before glucose, a significant fall in plasma and red cell potassium had occurred at the zero sample time. Red cell potassium had returned to control values at the end of the test, although plasma potassium was still decreased (Table 3 ). The group receiving furosemide simultaneously with glucose showed no significant change.

b) After chronic administration: There was no significant difference in plasma, red cell or total body cation values. Total body sodium was $100 \pm 8 \mathrm{mg}$ / $100 \mathrm{G}$ body weight compared with $123 \pm 6$ for controls, $p$ : N.S. Total body potassium was $224 \pm 17 \mathrm{mg} / 100 \mathrm{G}$ body weight compared with $255 \pm 10$ for controls, $p$ : N.S.

\section{The effects of acute administration of amiloride on blood glucose and plasma insulin}

a) Normal animals: Amiloride was injected as a suspension in normal saline at $1 \mathrm{mg}, 5 \mathrm{mg}$ and $10 \mathrm{mg} / \mathrm{kg}$ (4, 20 and $40 \mu \mathrm{M} / \mathrm{kg}$ respectively). A significant dose related increase in insulin secretion occurred one minute after injection in all groups, which persisted to 2.5 min after injection in the high dose group (Fig. 4). The one minute insulin values represent a 2,5 and 7 fold increase in insulin concentration respectively. Interestingly, no significant change in blood glucose occurred.

b) Diabetic animals: In the milder diabetic group (60 mg/kg streptozotocin) amiloride, $10 \mathrm{mg} / \mathrm{kg}$, caused 
a significant rise in plasma insulin, but this was only an increase of $25 \mu \mathrm{U} / \mathrm{ml}$, compared with $213 \mu \mathrm{U} / \mathrm{ml}$ for the same dose in normal animals (Table 4). No change in plasma insulin occurred in the ketotic hyperglycaemic group. As both diabetic groups contained very small numbers the results only show a trend and do not allow statistical comparison.
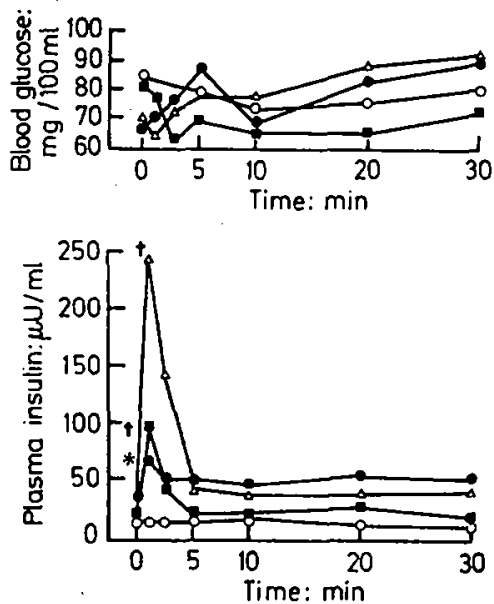

Fig. 4. The effects of acute administration of amiloride on blood glucose and plasma insulin in normal animals. Amiloride $1 \mathrm{mg} / \mathrm{kg}(n=3)$, shown by $-0,5 \mathrm{mg} / \mathrm{kg}$ $(n=6)$, shown by - or $10 \mathrm{mg} / \mathrm{kg}(n=5)$ shown by $\triangle-\triangle$, was given as an acute intravenous injection after the time 0 sample had been drawn. Control animals, shown by o-o $(n=5)$ received seline alone. Each point represents the mean of the values for each gicup. For clarity, the standard error of the mean is omitted, but significant differences compared with control values are shown by $*(p<0.05)$ or $\dagger(p<0.01)$

c) Adrenalectomised animals: A significant increase in insulin secretion occurred $1 \mathrm{~min}$ after the injection of $10 \mathrm{mg} / \mathrm{kg}$ amiloride (Table 4). There was marked attenuation of the absolute response compared with normal animals, but it represents a seventeen fold in. crease in plasma insulin compared with a nine fold increase in the normal group.

\section{$V$. The effects of acute administration of amiloride on intravenous glucose tolerance}

a) Normal animals: The response of blood glucose and plasma insulin to I.V. glucose $(0.5 \mathrm{~g} / \mathrm{kg})$ in control animals, animals given amiloride $5 \mathrm{mg} / \mathrm{kg}$ and $10 \mathrm{mg} /$ kg simultaneously with glucose, and animals pretreated with amiloride, $5 \mathrm{mg} / \mathrm{kg}, 30 \mathrm{~min}$ before glucose is shown in Fig. 5. Absolute blood glucose values in the amiloride treated groups were not significantly different from control values. Glucose disappearance rate was not affected. However, all the amiloride treated groups showed a highly significant increase in total $30 \mathrm{~min}$ insulin area (Table 2).

b) The effects of chronic administration of amiloride on intravenous glucice tolerance: Intravenous glucose tolerance tests were performed after the daily intra- peritoneal injection of amiloride $10 \mathrm{mg} / \mathrm{kg}$ for 10 days. Fasting blood glucose was significantly elevated in the experimental group with a slight elevation in plasma insulin (Fig. 6). Glucose disappearance was markedly

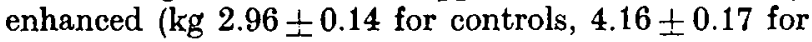
the amiloride treated group; $p<0.005$ ), and was associated with a significant elevation in peak initial in-
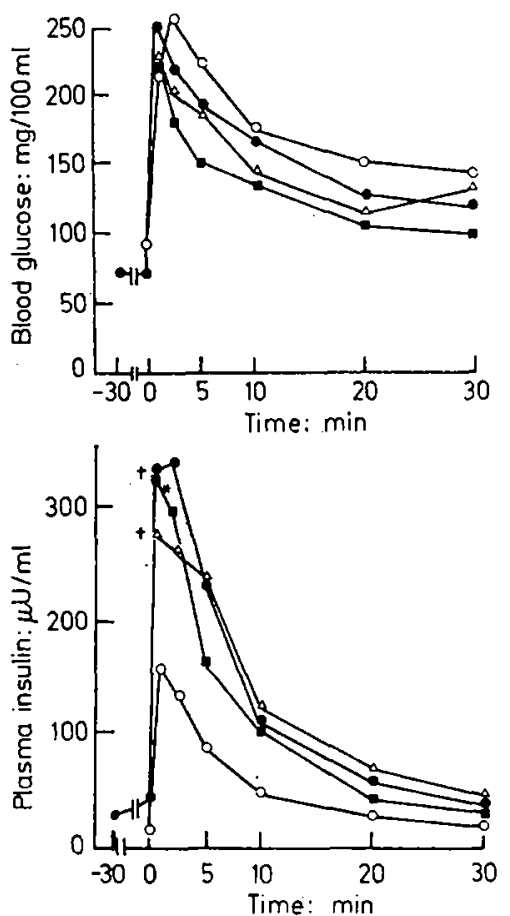

Fig. 5. The effects of acute administration of amiloride on blood glucose and plasma insulin during the intravenous glucose tolerance test. Amiloride $5 \mathrm{mg} / \mathrm{kg}$, shown by $\square-$ $(n=4)$ or $10 \mathrm{mg} / \mathrm{kg}$, shown by $\triangle-\triangle(n=5)$ was given by intravenous injection simultaneously with glucose $(0.5 \mathrm{G} /$ $\mathrm{kg}$ ) after the time zero sample had been drawn. Control animals, shown by $0-0(n=5)$ received glucose alone. Amiloride $5 \mathrm{mg} / \mathrm{kg}$ shown by $-(n=4)$ was given $30 \mathrm{~min}$ before glucose. Each point represents the mean of the values for each group. For clarity significant differ. ences in plasma insulin compared with control values are ghown only for the 1 min values $*(p<0.05, \dagger p<0.01)$. The plasma insulin values in all the amiloride treated groups at $2.5 \mathrm{~min}$ were also significantly increased $(p<0.05)$

sulin response and $5 \mathrm{~min}$ insulin area. $(481 \pm 23 \mu \mathrm{U}$ $\mathrm{ml}^{-\mathrm{i}} 5 \mathrm{~min}^{-1}$ for controls, $845 \pm 124 \mu \mathrm{U} \mathrm{ml}^{-1} 5 \mathrm{~min}^{-1}$ for the amiloride group; $p<0.025$ ).

\section{Cation changes after amiloride administration}

a) During the glucose tolerance test after acute administration of amiloride: No significant change in red cell or plasma cation values between control IVGTT and the high dose amiloride IVGTT occurred during the test.

b) After chronic administration: Cation values are shown in Table 5 . In contrast with furosemide there 
is a highly significant increase in plasma potassium in the experimental group $(7.0 \mathrm{mEq} / \mathrm{l}$ compared with $4.2 \mathrm{mEq} / 1 p<0.01$ ), associated with increased total body potassium. chronically, could not show any effect. Foy and Furman [15] found hyperglycaemia, glucose intolerance and impaired insulin response in the mouse. Most of these studies can be criticized because of the use of very

Table 3. The effects of acute administration of furosemide on red cell and plasma sodium and potassium during the intravenous glucose tolerance test ( \pm S.E.M.)

\begin{tabular}{|c|c|c|c|c|c|c|}
\hline \multirow{2}{*}{$\begin{array}{l}\text { Time } \\
(\min )\end{array}$} & \multicolumn{2}{|c|}{ Red cell $(\mu \mathrm{g} / \mathrm{g})$} & \multicolumn{4}{|c|}{ Plasma (mEq/1) } \\
\hline & Sodium & Potassium & $n$ & Sodium & Potassium & $n$ \\
\hline \multicolumn{7}{|l|}{ Control } \\
\hline & $471 \pm 16$ & $3496 \pm 360$ & 36 & $137 \pm 1$ & $4.8 \pm 0.1$ & 36 \\
\hline 30 & $547 \pm 88$ & $3213 \pm 153$ & 6 & $138 \pm 1$ & $4.6 \pm 0.2$ & 6 \\
\hline \multicolumn{7}{|c|}{$\begin{array}{l}\text { Furosemide } \\
2 \mathrm{mg} / \mathrm{kg}\end{array}$} \\
\hline & $482 \pm 87$ & $3292 \pm 98$ & 5 & $139 \pm 2$ & $4.0 \pm 0.1$ & 5 \\
\hline \multicolumn{7}{|c|}{$1 \mathrm{mg} / \mathrm{kg} 30 \mathrm{~min}$ before glucose } \\
\hline 0 & $541 \pm 110$ & $3156 \pm 112^{a}$ & 5 & $136 \pm 2$ & $4.0 \pm 0.2^{b}$ & $\mathbf{5}$ \\
\hline 30 & 459 土 39 & $3139 \pm 77$ & 5 & $139 \pm 2$ & $3.8 \pm 0.1^{\mathrm{B}}$ & 5 \\
\hline
\end{tabular}

Table 4. Blood glucose and plasma insulin after acute administration of amiloride $( \pm S . E . M$.

\begin{tabular}{|c|c|c|c|c|c|}
\hline \multicolumn{6}{|c|}{ Amiloride $10 \mathrm{mg} / \mathrm{kg}$} \\
\hline \multirow{2}{*}{$\begin{array}{l}\text { Time } \\
(\min )\end{array}$} & \multirow{2}{*}{$\begin{array}{l}\text { Saline } \\
\text { control }\end{array}$} & \multirow{2}{*}{ Normal } & \multicolumn{2}{|l|}{ Diabetic } & \multirow{2}{*}{ Adrenalectomised } \\
\hline & & & mild & moderate & \\
\hline \multicolumn{6}{|c|}{ a) Blood glucose $(\mathrm{mg} / 100 \mathrm{ml})$} \\
\hline-10 & $78 \pm 4$ & $68 \pm 4$ & $70 \pm 8$ & $320 \pm 30$ & $43 \pm 5$ \\
\hline 0 & $82 \pm 2$ & $72 \pm 6$ & $68 \pm 17$ & $330 \pm 35$ & $41 \pm 6$ \\
\hline 1 & $93 \pm 6$ & $65 \pm 2$ & $83 \pm 15$ & $315 \pm 31$ & $56 \pm 9$ \\
\hline 2.5 & $91 \pm 9$ & $73 \pm 5$ & $68 \pm 5$ & $361 \pm 58$ & $46 \pm 7$ \\
\hline 5 & $78 \pm 7$ & $79 \pm 7$ & $61 \pm 5$ & $341 \pm 48$ & $42 \pm 7$ \\
\hline 10 & $73 \pm 7$ & $79 \pm 5$ & $67 \pm 12$ & $362 \pm 78$ & $42 \pm 7$ \\
\hline 20 & $75 \pm 11$ & $89 \pm 5$ & $72 \pm 7$ & $349 \pm 76$ & $41 \pm 7$ \\
\hline 30 & $\begin{array}{l}80 \pm 12 \\
5\end{array}$ & $\frac{92 \pm 6}{5}$ & $\begin{array}{l}90 \pm 4 \\
2\end{array}$ & $377 \pm 58$ & $43 \pm 9$ \\
\hline \multicolumn{6}{|c|}{ b) Plasma insulin $(\mu \mathrm{U} / \mathrm{ml})$} \\
\hline-10 & $16 \pm 3$ & $27 \pm 6$ & $11 \pm 3$ & $6 \pm 1$ & $3 \pm 1$ \\
\hline 0 & $17 \pm 4$ & $33 \pm 3$ & $10 \pm 1$ & $7 \pm 1$ & $2 \pm 0.4$ \\
\hline 1 & $15 \pm 3$ & $246 \pm 18^{b}$ & $35 \pm 1$ & $5 \pm 2$ & $3421^{\mathrm{c}}$ \\
\hline 2.5 & $15 \pm 2$ & $142+16^{b}$ & $22+1$ & $6+1$ & $23+14^{c}$ \\
\hline 5 & $18 \pm 2$ & $47 \pm 12^{\mathrm{a}}$ & $18 \pm 6$ & $5 \pm 1$ & $5 \pm 1$ \\
\hline 10 & $17 \pm 3$ & $41 \pm 7^{\mathrm{a}}$ & $15 \pm 5$ & $6 \pm 1$ & $3 \pm 1$ \\
\hline 20 & $16 \pm 2$ & $42 \pm 3^{8}$ & $13 \pm 4$ & $4 \pm 1$ & $3 \pm 1$ \\
\hline 30 & $\frac{16 \pm 2}{5}$ & $\begin{array}{l}46 \pm 5^{\circ} \\
5\end{array}$ & ${ }_{2}^{13 \pm 5}$ & $\begin{array}{l}5 \pm 1 \\
3\end{array}$ & $3^{4 \pm 1}$ \\
\hline
\end{tabular}

$\left.\begin{array}{l}p<0.05 \\ p<0.01\end{array}\right\}$ compared with controls

c $p<0.01$ for paired differences with zero value; $p$ values significant but not stated for mild diabetic group as $n$ only 2 .

Mild diabetic animals received $60 \mathrm{mg} / \mathrm{kg}$ streptozotocin; moderate diabetic animals received $75 \mathrm{mg} / \mathrm{kg}$ streptozotocin.

\section{Discussion}

Previous studies in the rat have shown hyperglycaemia and impaired glucose tolerance after acute administration of furosemide $(50-200 \mathrm{mg} / \mathrm{kg})[9,14$, 24], while chronic administration (100 mg/kg/day) resulted in glucose intolerance [25]. In contrast, Senft et al. [12] using up to $200 \mathrm{mg} / \mathrm{kg}$ acutely or $200 \mathrm{mg} / \mathrm{kg}$ large doses and the use of anaesthesia, which in the rat is known to profoundly affect blood glucose and plasma insulin [26, 27, 28]. In addition, early sequential changes in insulin and glucose following diuretic administration have not been studied.

Our studies in the conscious rat have shown that low doses of furosemide suppress plasma insulin instantly with subsequent hyperglycaemia. The rate of 
fall of plasma insulin is of particular interest in that the normal half-life of insulin quoted in the literature is of the order of $3-4.8 \mathrm{~min}$ [29]. Our data suggest a halflife of about one minute. This disappearance rate could have been artifically enhanced by an extremely rapid shift of fluid into the intravascular compartment.
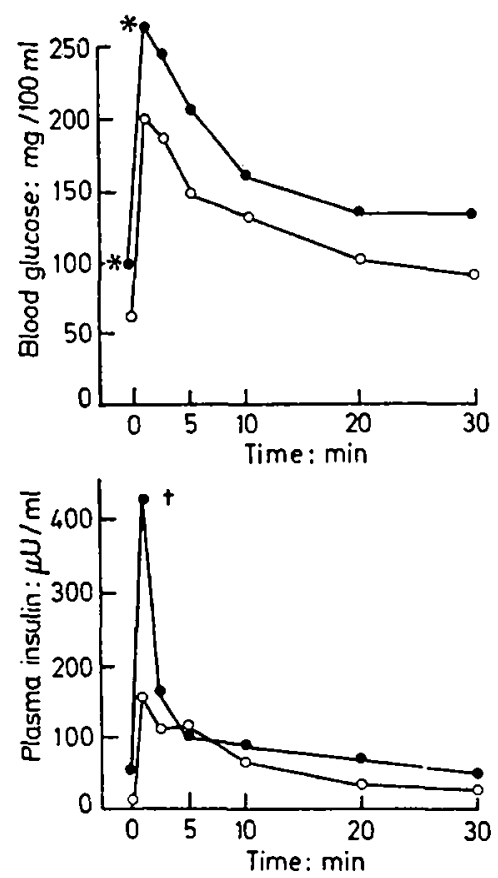

Fig. 6. The effects of chronic administration of amiloride on blood glucose and plasma insulin during the intravenous glucose tolerance test. Animals received amiloride $10 \mathrm{mg} / \mathrm{kg}$ (shown by - - ) or an equivalent volume of saline (shown by $0-0$ ) by daily intraperitoneal injection for 10 days. Intravenous glucose $(0.5 \mathrm{~g} / \mathrm{kg})$ was given $24 \mathrm{~h}$ after the last injection. Each point represents the mean of the values obtained for each group ( $n=4$ for both groups). Significant differences compared with control values are shown by ${ }^{*}(p<0.05)$ or $\dagger(p<0.01)$ secretion since it persisted in diabetic animals without a change in plasma insulin.

Possible hepatic mechanisms include catecholamine stimulation of glycogenolysis or inhibition of phosphodiesterase by furosemide, as suggested by Senft [12]. This hypothesis would explain the lack of effect on blood glucose in the ketotic hyperglycaemic animals in whom hepatic glycogen stores would be decreased. Decreased peripheral utilisation of glucose caused by furosemide has also been reported by Weller and Borondy [25].

A change in glucose space is implied by the decreased absolute blood glucose values during the IVGTT with furosemide. A decreased glucose stimulus at the $\beta$ cell could then result in an apparent decrease in insulin secretion. However, the $\frac{\Delta \mathrm{I}}{\Delta \mathrm{G}}$ ratio shows that the plasma insulin response was still reduced.

Insulin release could have been suppressed by a direct effect on the pancreas, through an effect on electrolyte exchange which is of major importance in insulin release [30]. However, red cell and plasma sodium and potassium showed minimal changes in the present study, although this does not preclude effects on the $\beta$ cell which need not be reflected in changes in the plasma, nor be analagous to red cell effects.

The absence of any effect on glucose tolerance after chronic administration and the absence of significant changes in tissue cations supports the observation in man that chronic administration of furosemide does not affect glucose tolerance [3].

In contrast, amiloride is a potent insulin secretagogue, with or without exogenous glucose. When given acutely alone, it caused a dose related increase in plasma insulin. Between 20 and $40 \mu \mathrm{M} / \mathrm{kg}$ gave a similar peak insulin response to $2800 \mu \mathrm{M} / \mathrm{kg}$ of glucose. The insulinogenic effect of a glucose load was potentiated both by the concurrent injection of amiloride,

Table 5. Red cell, plasma and total body sodium and potassium after chronic administration of amiloride $( \pm S . E . M$.

\begin{tabular}{|c|c|c|c|c|c|c|c|c|}
\hline & \multicolumn{2}{|c|}{ Red cell ( $\mu g / g)$} & \multicolumn{3}{|c|}{ Plasma (mEq/l) } & \multicolumn{3}{|c|}{$\begin{array}{l}\text { Total body (mg/100 g } \\
\text { B.W.) }\end{array}$} \\
\hline & Sodium & Potassium $n$ & Sodium & Potassium & $n$ & Sodium & Potassium & $n$ \\
\hline $\begin{array}{l}\text { Control } \\
\text { group }\end{array}$ & $425 \pm 22$ & $4134 \pm 55$ & $147 \pm 1$ & $4.2 \pm 0.1$ & 4 & $90 \pm .8$ & $181 \pm 6$ & 4 \\
\hline $\begin{array}{l}\text { Amiloride } \\
\text { treated } \\
\text { group }\end{array}$ & $491 \pm 40$ & $3734 \pm 1399^{a}$ & $141 \pm 3$ & $7.0 \pm 0.3^{b}$ & 4 & $78 \pm 4$ & $237 \pm 17^{\mathrm{a}}$ & 6 \\
\hline
\end{tabular}

$\left.\begin{array}{l}\text { a } p<0.05 \\ \text { b } p<0.01\end{array}\right\}$ compared with controls

Adrenalectomy abolishes the furosemide effects, implying that in normal animals they are secondary to catecholamine release. Foy and Furman [15] have suggested this mechanism in the mouse. However, the hyperglycaemia is not due to a decrease in insulin and by pretreatment. Chronic administration of amiloride also enhanced glucose stimulated insulin secretion.

Studies in man have given conflicting results on the effect of amiloride on blood glucose $[31,32,33,34,35]$ 
without investigating its effect on plasma insulin. No effect on glucose tolerance was reported by Pyörälä and Rantanen [36] while McNay et al. [37] showed increased glucose disappearance and $I / G$ ratios.

The lack of early changes in blood glucose suggests direct $\beta$ cell stimulation by amiloride. The diuretic promotes natriuresis and decreases potassium and hydrogen ion secretion by an effect on the renal tubule [18]. In frog skin [38] and toad bladder [39] amiloride inhibits sodium entry on the mucosal side of the cell. Inhibition of the sodium pump is not involved [18].

A structural feature common to amiloride and other compounds affecting apical celi sodium transport in amphibia is the presence of a guanidine group, which has a close structural relationship to the triply hydrated sodium ion [40]. An effect of amiloride on active potassium [41] and sodium [34, 42] transport in the human red cell has also been described. It is possible that the action of amiloride reflects a direct effect on $\beta$ cell sodium and/or potassium exchange.

Other guanidine derivatives, including arginine, stimulate insulin secretion in vivo and in vitro $[43,44$, 45, 46]. Amiloride shows similarities with arginine in that they both have synergistic effects with glucose, and both inhibit sodium transport in the toad bladder (Alberti, K.G.M.M. - unpublished observations). Thus it is possible that the stimulation of insulin secretion by all these compounds is due to the ionic effects of the guanidine group.

Acknowledgements. A.A.G. was the recipient of a Wellcome Junior Research Fellowship and the Beaney Scholar. ship in Materia Medica from Guy's Hospital, London. K.G.M.M.A. thanks the Wellcome Trust for financial support. The authors thank Hoechst Pharmaceuticals Ltd., Merck, Sharpe \& Dohme Ltd., and the Peel Medical Research Trust, for financial grants, Miss H. Kuresova and Miss $\mathrm{S}$. Warne for technical assistance, and Professor P.B. Beeson for facilities to carry out this work.

\section{References}

1. Peters, G., Roch-Ramel, F.: Handbook of Experimental Pharmacology. Band XXIV Diuretica, p. $337-$ 341. Berlin-Heidelberg-New York: Springer 1969.

2. Wales, J.K., Viktora, J.K., Wolff, F. W.: The effect of hydrochlorothiazide in normal subjects receiving high fat or high carbohydrate diets. J. Amer. Med. Sci. 254, 499-505 (1967).

3. Anderson, J., Godfrey, B.E., Hill, D. M., Munro-Faure, A.D., Sheldon, J.: A comparison of the effects of hydrochlorothiazide and of Frusemide in the treatment of hypertensive patients. Quart. J. Med. 40, $541-560$ (1971).

4. Kohner, E.M., Lowy, C., Dollery, C.T., Schumer, B.: Effects of diuretic therapy on glucose tolerance in hypertensive patients. Lancet 1971 I, 986-990.

5. Zamrazil, V., Dvořák, V., Oškera, J., Zamrazilova, E.: The influence of hydrochlorothiazide upon glucose tolerance test after prednisone. Metabolism 16, 445450 (1967).

6. Kadota, I., Nishimura, Y., Ishigani, R., Yoshida, A.: Abnormal carbohydrate metabolism induced by thiazide diuretics. Folia endocr. jap. 40, 277-280 (1964).
7. Meng, K., Kroneberg, G.: Erhöhung des Blutzuckers der Ratte durch Saluretica. Arch. exp. Path. Pharmak. 247, $351-352$ (1964).

8. Meng, K., Kroneberg, G.: Untersuchungen an der Ratte zur Frage der diabetogenen Wirkung von Saluretica. Arch. exp. Path. Pharmak. 251, 433-444 (1965).

9. Wales, J.K., Grant, A., Wolff, F.W.: Studies on the hyperglycaemic effects of nonthiazide diuretics. J. Pharmacol. exp. Ther. 159, 229-235 (1968).

10. Weller, J.M., Borondy, M.: Effects of benzothiadiazine drugs on carbohydrate metabolism. Metabolism $14,708-714(1965)$.

11. Watson, L.S., van Pelt, S.M., Winter, C.A.: Effect of chlorothiazide on blood glucose of rats. Fedn. Proc. 23, 438 (1964).

12. Senft, G., Losert, W., Schultz, G., Sitt, R., Bartelheimer, K.H.: Ursachen der Störungen in Kohlehydratstoffwechsel unter dem Einfluß sulfonamidierter Diuretica. Arch. exp. Path. Pharmak. 255, 369-382 (1966).

13. Tabachnik, I. I. A., Gulbenkian, A., Yannell, A.: The hyperglycaemic activity of benzothiadiazine and other diuretics. Life Sci. 4, $1931-1936$ (1965).

14. Foy, J.M.: Acute diuretic induced hyperglycaemia in rats. Life Sci. 6, 897-902 (1967).

15. Foy, J.M., Furman, B.L.: Effects of diuretics on mouse blood sugar following single dose administration. Br. J. Pharmacol. 41, 287-297 (1971).

16. Conn, J.W.: Hypertension, the potassium ion and impaired carbohydrate tolerance. New Engl. J. Med. $273,1135-1143(1965)$.

17. Rapoport, M.I., Hurd, H. F. : Thiazide induced glucose intolerance treated with potassium. Arch. int. Med. exp. 113, 405-408 (1964).

18. Baer, J.E., Jones, C.B., Spitzer, S.A., Russo, H.F.: The potassium sparing and natriuretic activity of $\mathrm{N}$. amidino-3,5-diamino-6-chloropyrazinecarboxamide hydrochloride dihydrate (amiloride hydrochloride). J. Pharmacol. exp. Ther. 157, 472-485 (1967).

19. Soeldner, J.S., Slone, D.: Critical variables in the radioimmunoassay of serum insulin using the double antibody technic. Diabetes 14, $771-779$ (1965).

20. Aynsley-Green, A., Alberti, K. G.M.M.: Serum-insulin or Plasma-insulin? Lancet 1972 I, 318-319.

21. Bergmeyer, H.U., Bernt, E.: Methoden der enzymatischen Analyse, p. 123. Weinheim: Verlag Chemie 1962.

22. Ikkos, D., Luft, R.: On the intravenous glucose tolerance test. Acta. endocr. Copenh. 25, 312 - 334 (1957).

23. Seltzer, H.S., Allen, E.W., Herron, A.L., Jr., Brennan, M.T.: Insulin secretion in response to glycemic stimulus: Relation of delayed initial release to carbohydrate intolerance in mild diabetes mellitus. $J$. clin. Invest. 46, 323-335 (1967).

24. Formanek, K., Kenner, T.: Special features of the action of a new diuretic, Brit. J. Pharmacol. Chemother. 26, 27-33 (1966).

25. Weller, J.M., Borondy, M.: Effect of Furosemide on glucose metabolism. Metabolism 16, 532-536 (1967).

26. Biebuyck, J.F., Alberti, K.G.M.M.: Influence of altered dietary and endocrine states on the effects of anaesthetic agents on serum insulin and blood metabolites. Submitted for publication (1972).

27. Aynsley-Green, A., Biebuyck, J.F., Alberti, K.G.M. M.: Anaesthesia and insulin secretion: A comparative study on the effects of diethyl ether, halothane, pen. tobarbitone sodium and ketamine hydrochloride on intravenous glucose tolerance and insulin secretion in the rat. Submitted for publication (1972).

28. Hawkins, R.A., Alberti, K.G.M.M., Honghton, C. R. S., Williamson, D.H., Krebs, H.A.: The effect of 
acetoacetate on plasma insulin concentration. Biochem. J. 125, $541-544$ (1971).

29. Sonksen, P.H., Turner, R.L., Grayburn, J.A., Newman, G.B., Nabarro, J.D.N.: Measurement of insulin delivery rate in man. J. clin. Endoc. Metab. 33, 279-286 (1971).

30. Hales, C.N., Milner, R.D.G.: Cations and the secretion of insulin from rabbit pancreas in vitro. $J$. Physiol. (Lond.) 199, $177-187$ (1968).

31. Rorive, G., Hagemeijer, F., Luyckx, A., Van Cawonberge, H.: Etude clinique d'un nouveau diurétique doué d'un effet d'epargne potassique: le chlorhydrate d'amiloride (MK 870). Presse Méd. 76 (23), 1127-1128 (1968).

32. Esch, I.: Die Behandlung dekompensierter Herzkranker mit einem neuen Kelium konservierenden Diuretikum. Wien med. Wschr. 118 (50), 1074-1078 (1968).

33. Brailovsky, D., Kukolj, S., Rebolledo, H.: Uso del clorhidrato de amilorida (MK 870) en el.tratamiento y prevencion de la deplecion de potasio. Revta. med. Chile 95, 299-303 (1967).

34. Gross, W.: Wechselwirkungen zwischen Kalium und Glukose in Erythrocyten und Serum nach Gabe von Amilorid und Etacrynsäure. Sixth Symp. Ges. Nephrol. Vienna 1968, p. 323-327. Wien: Verlag Wien Med. Akad. 1969.

35. Lant, A., Smith, A.J., Wilson, G.M.: Clinical evaluation of amiloride, a potassium sparing diuretic. Clin. Pharmac. Ther. 10, 50-63 (1969).

36. Pyörälä, K., Rantanen, I.: Effect of amiloride hydrochloride (MK 870) on blood pressure, serum electroly. tes and glucose tolerance in patients with mild hyper. tension. An. Med. intern. Fenn. 57, 91-97 (1968).

37. McNay, J., Hornbrook, K.R., Oran, E.: Intolerance of diabetic patients to positive $\mathrm{K}+$ balance despite enhancerno.t of glucose disappearance rate. J. clin. Invest. 47, $68 \mathrm{~A}(1868)$.

38. Salako, L. A., Smith, A.J.: Effects of amiloride on active sodium transport by the isolated frog skin: Fvidence concerning site of action Br. J. Pharmac. Chemother, 38, 702-718 (1970).

39. Bentley, P.J.: Amiloride: a potent inhibitor of sodium transport across the toad bladder. J. Physiol. (Lond.) 195, 317-330 (1968).

40. Fastier, F. N.: Structure-activity relationships of amidine derivatives Pharmacol. Rev. 14, 37-90 (1962).

41. Sachs, J.R., Welt, L.G.: Concentration dependence of active potassium transport in the human red blood cell in the presence of inhibitors. $J$. clin. Invest. 47, $949-959$ (1968).

42. Wessels, F.: Der Finfluß von Etacrynszure und Amilorid auf den Natriumtransport der Erythrocyten des Menschen in Vitro. Arzneimittel-Forsch. 19, 19591961 (1969).

43. Alsever, R. N., Georg, R.H., Sussman, K. E.: Stimulation of insulin secretion by Guanidinoacetic acid and other Guanidine Derivatives. Endocringlogy 86, 332 $336(1970)$.

44. Malaisse, W.J., Tinant, A., Ooms, H. A., Franckson, J. R.M.: Metabolic effects of $\gamma$-guanidinobutyramide. I. In vivo study in anaesthetised dogs. Hormone Metab. Res. 1, 258-265 (1969).

45. Malaisse, W.J., Mandelbaum, I.M., Franckson, J.R. M.: Metabolic effects of $\gamma$-guanidinobutyramide. II. In vitro studies on Muscle, Adipose tissue and the Endocrine pancreas. Hormone Metab. Res. 2, 21 -27 (1970).

46. Blazquez, E., Lopez-Quijada, C., Candela, J.L.: The effect of $\gamma$-guanidinobutyramide on the secretion ard synthesis of insulin in vitro. Diabetologia 6, 447-448 (1970).

A. Aynsley-Green, M. B.

The United Oxford Hospitals

Nuffield Dept. of Clinical Medicine

The Radcliffe Infirmary

Oxford

England 